\title{
The Euroisation of Banks' Portfolio and the Credit Risk in Albania
}

\author{
Anila Mançka, Dr \\ Eleni Vangjeli, Dr
}

University “Fan S. Noli” Korçë, Albania; Email: arapi_anila@yahoo.com

Doi:10.5901/ajis.2015.v4n3s1p108

\section{Abstract}

The loans portfolio of the Albania banking system has a high level of euroisation, as well as in other countries of the region. In Albania, the loans in foreign currency represent $49 \%$ of the total loans outstanding. The high level of the euroisation of banks' portfolio exposes them to the risk of direct and indirect exchange rate. Although the banks have been protected from the direct exchange rate, they are exposed to the risk of indirect exchange rate. This risk might increase if the national currency depreciates according to other currencies. At the end of 2014, the loans denominated in foreign currency to the borrowers, whose incomes are in All (Albania currency) were 31.3\%, representing 186.4 billion All of the total loans and approximately $50 \%$ of the loans denominated in foreign currency. This portion of the loans is influenced by the changes of exchange rates, thus the indirect credit risk may increase, as a result of the difficulties of the borrowers to pay their loans. This research aims to provide evidence, based on a statistical analysis, that the instability of the national currency, in relation to Euro and the American Dollar, have influenced upon the systematic credit risk in Albania.

Keywords: systematic credit risks, exchange rate, instability, national currency.

\section{Literature Review}

It is very difficult to measure the sensitivity of the banking system against unpredicted losses that may be caused by the repayment of loans. Many realized studies have been created empirical models that assess the impact of various macroeconomic factors in the quality of the banking portfolio, specifically the ratio of nonperforming loans to total loans. Credit risk is measured by microanalysis, which determines unsystematic risk, and also by macro analysis, that assess the systematic risk ${ }^{1}$. Foreign scientific researches ${ }^{2}$ have determined that the level of an investment risk depends on many factors that are divided in two groups. The first group includes macroeconomic factors which systematically affect the risk of all investments and they aren't controlled or avoided. These factors cause the systematic credit risk. The second group includes factors that affect the risk of particular investments and cause unsystematic risk.

\section{Aim and Objectives}

The main aim of this research is to analyse the tendency of credit risk. Furthermore by using national and international reliable information the study aims to analyze the relationship between macroeconomic factors and the indicators that measure the quality of Albanian loans portfolio. The main aim of the statistical analysis is to evaluate the influence of the unsustainability of domestic currency (ALL) on the value of systematic credit risk in the Albanian banking portfolio. The study focuses on two main areas. First we will give our estimates about the progress of credit risk by identifying some important points in time that have significantly affected the tendency of non-performing loans. Secondly, we will study the relationship between credit risk, which is measured by the ratio of nonperforming loans to total loans outstanding, and the unsustainability of the domestic currency exchange rate against euro and US dollar.

\footnotetext{
1 (Morton Glantz, "Managing Bank Risk”, 2004).

2 Sunders, 1997. Asarnow, 1996. Crouhy, Galai and Mark, 2000. Carty and Lieberman 1996. Carty and Fons, 1993. 


\section{Credit Growth and the Tendency of Nonperforming Loans}

Over the last years, the activity of Albanian banking system is substantially increased. The weight of the bank system's assets to GDP was $90.5 \%$ at the end of 2013 and $91.7 \%$ at the end of 2014 .

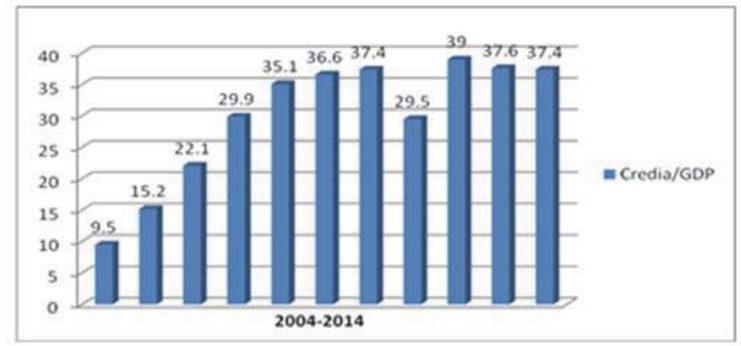

Data to construct the graph from the Bank of Albania

South East Europe. Regular Economic Report, January 2015

Figure 1. Private sector loans of the Albania banking system to GDP

The expansion of lending base has been identified as one of the most vigorous activities and it has a major impact not only in the banking sector, but on the entire economy. Despite the high rates of growth, Albania has a low ratio of private sector loans to GDP in the Balkan region. This relates to the stage of economic and financial development of our country and with the low base of lending. Therefore Albania has started the lending from a very low base. Large resources of funds encouraged high credit growth in Albania and in other countries. It was considered a positive development due to the low level of financial development in these countries. The credit expansion was simulated by the consolidation's process of the banking system caused by the increasing presence of foreign banks. A characteristic was the high financing of branches from mother banks and the use of these funds to give loans with the higher interest rates. In this way, foreign banks acquire high profits by the difference between interest rates in the mother country and in the location where their branches do business. In addition, the competition among banks became a driving force for encouraged them to aggressively increase supply for loans and reduce the interest rates, which caused the increasing demand for loans.

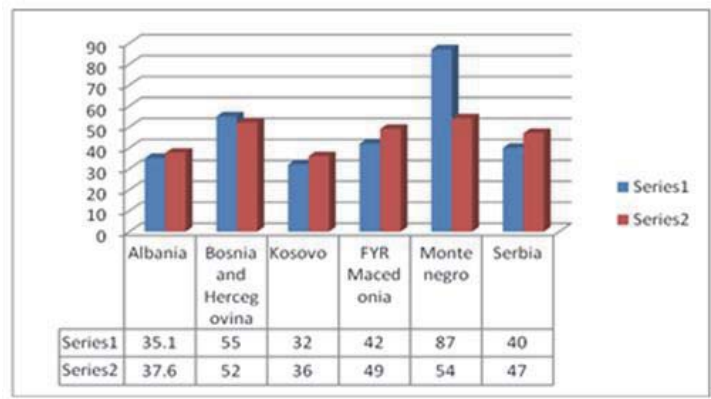

Dates from IMF's International Financial Statistics and World Economic Outlook database (May 2015).

Figure 2. Private sector loans to GDP for the region ${ }^{3}$

Despite the benefits, the rapid rates of credit expansion introduced a series of risks to financial stability.

First undermining the credibility of the borrowers the banks increased the potential risk, because they increased the possibility of deterioration of the loan portfolio in the economic downturns and in the time of decreasing the lending 
activity. Second the close relationship between the affiliates and the mother banks for financial resources increased the exposure of banks to the risk of finding resources, thus making them vulnerable to external developments. For the period 2004-2008 the ratio loans/GDP grew an average of $20 \%$ in these countries. This increase was especially high for our country, an average of $39.65 \%$. The world economic financial crisis had a negative impact on the banking system in Albania and in other countries of the region. The banking systems suffered significant deterioration of the financial indicators, low profit, high growth of non-performing loans, while capital adequacy ratio was within tolerable limits. These developments led to a major decrease of the credit growth, combined with other factors such the avoidance of high risk, the constriction of the credit standards and the uncertainty of the economic future. Figura 2, 3 and 6.

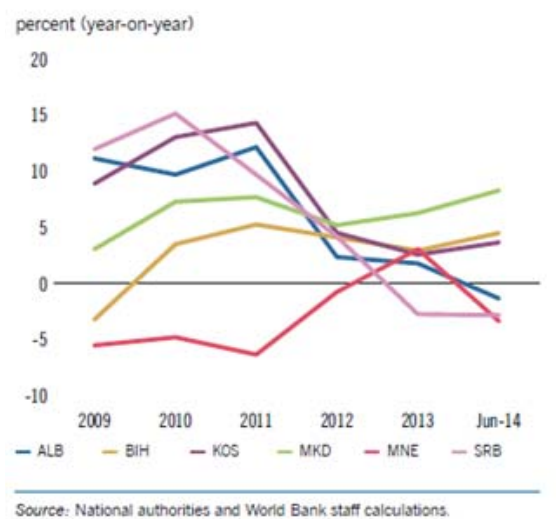

South East Europe. Regular Economic Report, January 2015

Figure 3. The growth rate of private sector credit to GDP for the region

As regards our country, the average rate of credit growth during the period 2011-2014 was about 3.1\%. Figura 4. While in November 2014, the ratio of nonperforming loans to total loans resulted $24.88 \%$ and in April 2015 it was $22.69 \%$. In addition in March 2015, the return on equity was $20,25 \%$ and the capital adequacy ratio was $15.78 \%$. Figura 7 . Albanian banking system, as well as the other countries in the region represents a high level of euroisation of his portfolio. For example the foreign currency lending as a percentage of total loans outstanding represent $72 \%$ in Serbia, $64 \%$ in Bosnia -Hercegovina and 63\% in Albania at the end of 2012. While at the end of 2014, the credit in foreign currency in Albania is $49.1 \%$ of total loans. The growth of the foreign currency lending has been caused by low interest rates for the loans in euros, compared to loans in domestic currency. This difference in the interest rates is related to the dominant presence of the foreign banks and their ability to financing from mother banks with lower interest rates. The high level of euroisation of the credit portfolio exposes banks to the risk of direct and indirect exchange rate. Because the euroisation was applied not only to assets but also to deposits, the net exposure of banks is reduced.

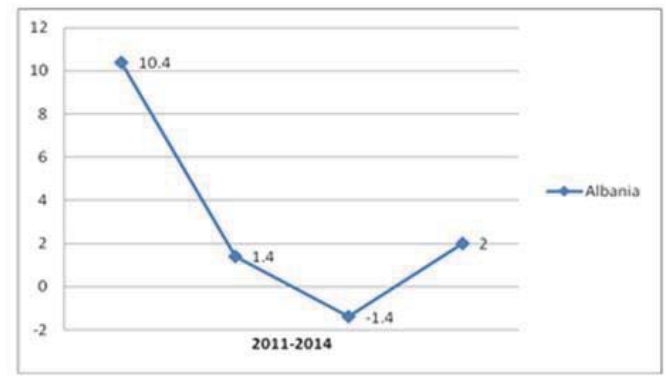

Figure 4. The growth rate of private sector credit to GDP in Albania

Source: South East Europe. Regular Economic Report, January 2015 
Table 1. The structure of loans by currency in Albania banking system, in million All

\begin{tabular}{|l|c|c|c|c|c|c|c|}
\hline Indicators & $\mathbf{2 0 0 9}$ & $\mathbf{2 0 1 0}$ & $\mathbf{2 0 1 1}$ & $\mathbf{2 0 1 2}$ & $\mathbf{2 0 1 3}$ & $\mathbf{2 0 1 4}$ & $\mathbf{2 0 1 5}$ \\
\hline Total of loans & 430,994 & 472,564 & 531,044 & 543,970 & 537,377 & 549,108 & 545,122 \\
\hline Loans for business & 291,214 & 330,388 & 389,426 & 401,699 & 394,660 & 404,514 & 398,287 \\
\hline (ALL) & 76,734 & 89,529 & 118,862 & 142,845 & 145,978 & 154,107 & 153,812 \\
\hline (USD) & 26,832 & 31,187 & 36,138 & 34,546 & 31,784 & 39,589 & 40,309 \\
\hline (EUR) & 186,942 & 209,347 & 234,203 & 224,224 & 216,840 & 210,780 & 204,126 \\
\hline Other currencies & 706 & 324 & 222 & 84 & 58 & 38 & 40 \\
\hline Loans to individuals & 139,780 & 142,176 & 141,618 & 142,271 & 142,717 & 144,594 & 146,835 \\
\hline (ALL) & 56,239 & 59,412 & 61,525 & 63,554 & 65,588 & 70,607 & 72,378 \\
\hline (USD) & 2,331 & 2,254 & 2,253 & 1,901 & 1,325 & 1,293 & 1,381 \\
\hline (EUR) & 80,748 & 80,002 & 77,355 & 76,372 & 75,434 & 72,354 & 72,700 \\
\hline Other currencies & 461 & 508 & 485 & 444 & 370 & 340 & 377 \\
\hline
\end{tabular}

Source: Bank of Albania

The weight of the foreign currency assets and liabilities to total assets at the end of 2014 was respectively $56.4 \%$ and $52.4 \%$. Magnitude of the open position is considered limited, therefore the direct exchange rate is considered moderate. Although the banks may be protected from the risk of direct exchange rate, they are exposed to the risk of indirect exchange rate, which increases by depreciation of the domestic currency, since borrowers are potentially exposed to. At the end of 2014, the total foreign currency loans the borrower whose income have been in ALL, represented $31.3 \%$ of total loans and $50 \%$ of foreign currency loans. This part of the loan represents a potential channel of the negative impact to adverse changes of the exchange rate on the banking sector. These may be accompanied with grow of the indirect credit risk as a result of the difficulties of the borrowers to pay their loans. Nevertheless worth noting that the picture of the series of non-performing loans about banking system in Albania suggests the existence of a upward trend. Figure 9 shows the performance of the quality of the banking system, respectively non-performing loans to total loans.

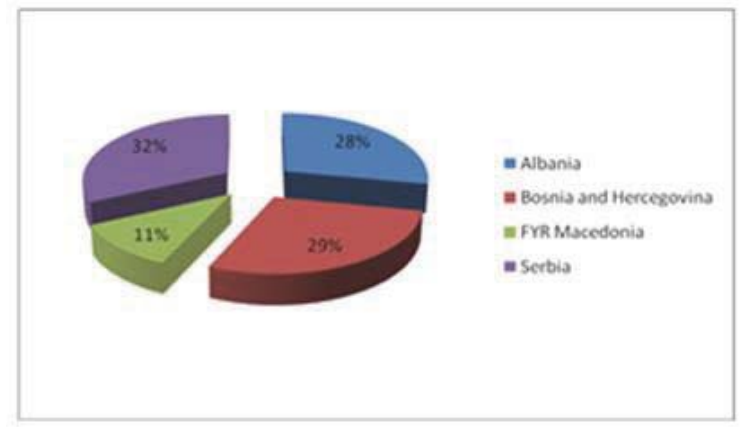

Figure 5. Euroisation of the bank portfolio in the region, 2012.

Source: South East Europe. Regular Economic Report, January 2015

It is obvious the constantly upward tendency of non-performing loans to total loans, a trend that realizes a significant increase in the third quarter of 2008. This sharp growth has been due to the negative effects of the economic and financial crisis on our banking system.

In our economy the influence of this crisis gradually intensified during the last quarter of 2008. The uncertainty led by the global financial system shock was reflected in the withdrawal of a part of deposits from banking system during the last quarter of 2008. These withdrawals led to liquidity problems in the system and were followed by increasing of the interest rates. 


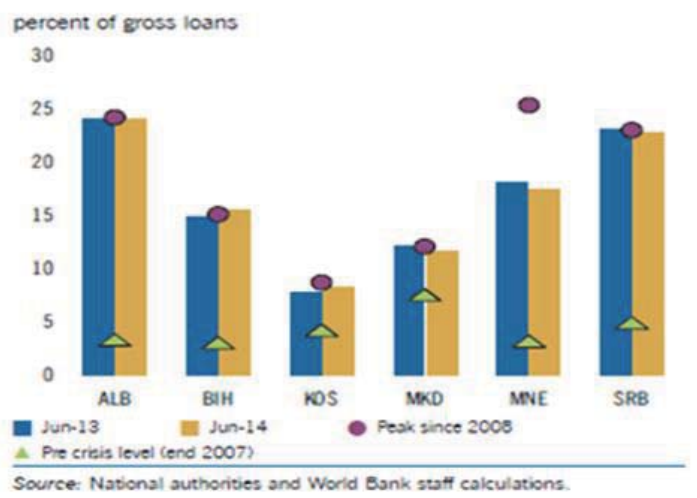

South East Europe. Regular Economic Report, January 2015

Figure 6: Non-performing loans to total loans for the region

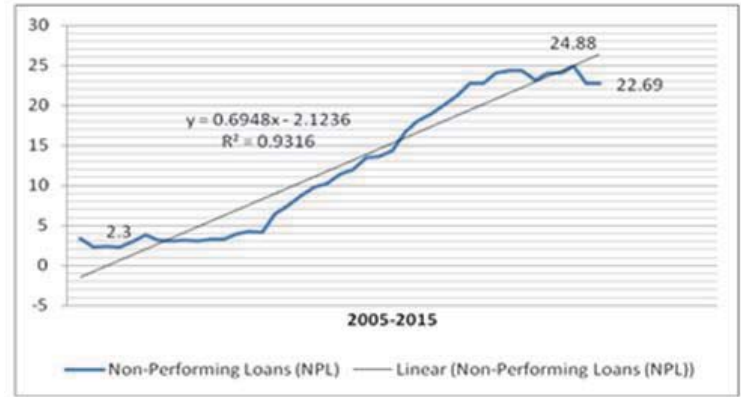

Data to construct the graph from the Bank of Albania

Figure 7. Non-performing loans, NPL.

On the other hand, this situation naturally led to the reduction of the system's ability to lending the economy and consequently and significantly led to the slowdown of lending beginning since this period. It is obvious that the global economic and financial crisis has accelerated the growth of non-performing loans in Albanian banking system. The negative economic influences against the banks significantly reduced the level of credit in the economy. This not only adversely affected the economy but at the same time let changeless the loan portfolio in banking level. Expressed mathematically, the level of non-performing credits increases sharply compared to the denominator of a constant basis. Before the crisis, the credit grew more than the level of economic growth, the expansion of unstudied credit.

For the period 2004-2008 the annual rates of the credit growth were respectively: $60.4 \% ; 45.5 \% ; 35.3 \%$ and $17.4 \%$, higher than the average rates of credit growth in the countries of the region. The banks increased the aggressive competition for the market share and high profits. For the period 2004-2008, ROE was 22.2\%; $20.2 \% ; 20.7 \%$ and $11.4 \%$, respectively, higher than in the region. Underestimating the credibility of the borrowers and the failure to asses of the credit risk in periods of sustainable economic and credit expansion, may be a significant factor in the growth of nonperforming loans during the periods of economic slowdown and contraction of the credit activity. This part of the borrowers affects more quickly and hardest in the deterioration of the lending indicators. The slow economic growth cause more deterioration of the credit grade and the lower grades of the credit have a higher correlation with the macroeconomic factors. 


\section{Conclusions and Recommendations}

$>$ The deterioration of the main macroeconomic indicators after the crisis, (lower GDP growth rate, the growth of the consumer price index, the underestimation of the domestic currency relation to foreign currencies, the increase in the unemployment rates, the decline of the exports and the remittances, the lack of funding, the decrease of consumption and private investment) deteriorated the micro environment of the businesses and the individuals by increasing the ability to delay on the loan payments and increased the non-performing loans. The economic experts and managers of the risk departments in some banks in our country explain that besides the specific factors of industry, businesses and individuals, the volatility of the macroeconomic factors have the most influence on the growth of the credit risk in Albanian banking system. This part of the credit risk attributable to the impact of the macroeconomic factors, is called systematic credit risk, which can not be eliminated or avoided.

$>$ The depreciation of All (Albania currency) and the appreciation of the euro have adversely affected the borrowers who have a loan in euros. Most of the credit provided by our banking system is in euros, $51 \%$ in 2015. The total foreign currency loans to the borrower whose income has been in ALL represents $31.3 \%$ of total loans outstanding.

$>$ Then the increase of the non-performing loans as a result of the rising the exchange rate All / Euro is expected.

$>$ In addition, the business has approximately $73.1 \%$ of total loans and $74.7 \%$ of loans in euros. The businesses are presented as debtors in the banking system. The debtor position in foreign currency is high and it keeps growing, and the businesses is exposing to the indirect risk of the exchange rate.
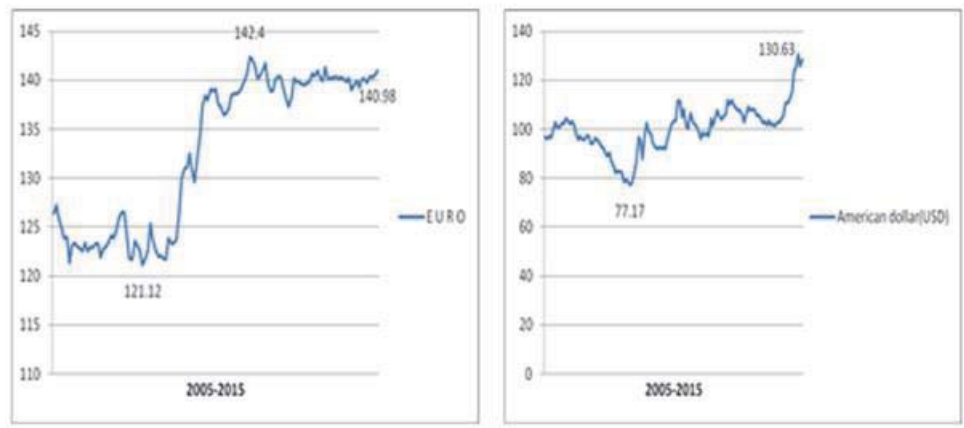

Data to construct the graph from the Bank of Albania

Figure 8. The exchange rate performance ALL / EUR and ALL / \$. (Monthly data)

$>$ In Figure 8 it is observed the continuous increase of the exchange rate All / Euro from one quarter to the next. After the crisis the values of the exchange rate are higher than the average over the period. The financial and economic crisis led to a decrease of the income by remittances, a reducing of the upward rhythm of the exports and the declining of the foreign investment.

$>$ These factors led to the significant appreciation of euro against ALL. But this means more ALL to repay the loan installment by the borrowers who have a loan in euro terms. As a result, the possibility to delay or dishonor the payment will crease leding to the increasing of non-performing loans in the banking portfolio.

$>$ In addition the All / \$ ratio represents a long-term growing tendency, resulting in the deterioration of the quality of the banking portfolio. But the depreciation of the ALL against the euro was greater as compared to the dollar and knowing that the loans in dollar are $8 \%$ of the loan portfolio, we conclude the important impact of the growing euro in the growing credit risk. 


\section{References}

Albania bank "Financial Stability Report, 6 m II" 2013.

Albania bank "Financial Stability Report, 6 m I" 2014

Albania bank "Financial Stability Report, 6 m II" 2014.

Asarnow, 1996. "Best practices in loan portfolio management. Journal of Lending and Credit Risk Management 78 (7):14-24.

Belkin, Suchower and Forest 1998. "The effect of systematic credit risk on loan portfolio value-at-risk and loan pricing. CreditMetrics Monitor, $17-28$.

Bostjan Aver. (2007), "An empirical of credit risk analysis of Slovenian banking System".

Europian Bank for Reconstruction and Development. (2010), "Recovery and reform". Transition Report.

IMF, (april 2015), "Global Financial Stability Report".

Glantz, Morton, (2003), Managing Bank Risk An introduction to Broad-Base Credit Engineering.

IMF, (april 2015), "International Financial Statistics and World Economic Outlook database

Kaminsky, Lizondo and Reinhard, (1998) "The twin crises: The causes of banking and balance of payments problems", International Finance Discussion Paper.

Kaminsky and Reinhard, (1999), "The twin crises: The causes of banking and balance of payments problems" American Economic Review.

Kern / Reitzig, (2000), "Comparative analysis of credit risk model".

Richard Roll and Stephen Ross, (January/Fabruary 1995). "The arbitrage Pricing Theory Approach to Strategic Portofolio Financial," Analysts Journal.

Saunders, (1997), "Financial institutions management: A modern perspective. $2^{\text {nd }}$ ed. New York: Irwin.

Regular Economic Report, (January 2015) South East Europe.

Tom Wilson and McKinsey, (1997) "Credit Portfolio View".

www.bankofalbania.org

www.instat.gov.al 